\title{
XI. Extract of a memoir on elasticity
}

\section{Barruel}

To cite this article: C. Barruel (1800) XI. Extract of a memoir on elasticity, Philosophical Magazine Series 1, 6:21, 51-56, DOI: 10.1080/14786440008677186

To link to this article: http://dx.doi.org/10.1080/14786440008677186

$$
\text { 册 Published online: } 18 \text { May } 2009 .
$$

Submit your article to this journal 전

III Article views: 2

Q View related articles $\sqsubset$ 
pretation is obvious, becaufe the new inoculation will not fupply them with patients.

I was treated with fome derifion the other and am every day : a perfon faid, that, as he had inoculated many for the cow-pock, he knew the complaint, and its treatment, better than myfelf.

I am greatly forry the difeafe above fpoken of is fo well known among the cow-people, as many eminent men will lofe great fums in the year by the fmall-pox being fuperfeded.

Query, Whether Fame, with her babbling tongue, fome future time, may not convey ruftic vaccine intelligence to fome metropolitan friends, and fo overturn your excellent Inftitution, which, I am informed, is on the tapis*?

Dear Sir, believe me,

With the greateft deference and refpect,

Your moft humble Servant and Pupil,

Winfow, Bucks.

J. TURNER。

XI. Extract of a Memoir on Elafticity. By C. Barruelt. $\mathrm{T}$

$\mathrm{HE}$ author of this memoir endeavours to explain the caufe of the elafticity of bodies by the help of caloric. After laying it down as a principle, that this fluid is eminently elaftic; that it is internofed between the integrant molecula of bodies, which is proved by their porofity; he hopes, from thefe two principles, to deduce confequences leading to this refult. But whatever may be affigned as the caufe of elaiticity, caloric, at any rate, has a great hare in the phenomena which it exhibits.

The different fyftems adopted by philofophers refpeeting the caufe of elafticity, are, in the author's opinion, either vague or evidently erroneous. It cannot, he thinks, be afcribed to a repulfive force, with which the moles!? are endowed, and which increafes as they approach; for the

* It appears, by the vaccine inoculation in the coinntry, that medical initance $x$ as farcely neceffary

t From the Ainales de Chimie, No. o:

$\mathrm{H}$ \%

exiftence 
exiftence of this force is merely hypothetical. Nor can it be faid that the elafticity is owing to air interpofed between the molecula, fince the phenomena of elafticity manifeft themfelveg in vacuo.

C. Barruel is of opinion, that if we frould afcribe the caule of elatticity to calorie, this quetion would remain to be anfwered; Why is caloric fo emincntly elaftic? We know, indeed, fays be, that the affinity of molecula of water to thofe of fponge, into the pores of which they introduce themfelves, produces an increafe of the volume of that fponge; but the caufe of the reciprocal attraction of thefe differcnt moleculax remains unknown. Befides, we could not sefufe to almit that the elaticity of caloric would arife from the property which the molecula of this fuid might have of repelling each other: a property the more probable, as it is obferved in the electric Huid, with which caloric has fo great an analogy. In a word, we may be fatisfied with adnitting its elafticity as a finct from which we fet out, as from an incontedible principle.

The author then proceeds immediately to his object, and examines in what mamner caloric acts upon bodies. It dilates them by means of a reciprocal affinity between it and their molecula. Thefe afinities are variable; but it is certain that, in regard to the fame fubltance, they decreafe in 'proportion as the diftances increale, and that their action is at lengtin reduced to zero.

Now, if we fuppofe a given quantity of caloric inslofed in a receiver incapable of acting on this fuid, it will every-where diffife itelt in an mifom manne. If we then introduce a molecule of mater, the caloric will br unequally condenfed around it, in virtuc of the nucqual a iton which it exercifes on the parts of the Aluid at different diftances from it, and it will be furreunded by a kind of igneons atmofphere, compoled of firata of dinerent denfities. If a fecond molecule be introduced, the fame efects will take place, and every thing will romain in the fume frate as long as the molecnles we at a difance from each other equal to the diameter of their atmofpheres: nothing is changed but the temperature. I w when the melecta are brounth fo near each other th at 
their diftance is lefs than that diameter, their atmofpheres will be compreffed, and the parts in contast will affume more denfity and a higher temperature, and which is not in equilibrium with that in the reft of the receiver. Thefe parts deprive themfelves of a portion of their caloric, which is diftributed among the other ftrata of thefe atmofpheres until the equilibrium is reftored.

When the molecula are made to approach each other gently, the compreffion of the atmofpheres and their reeftablithment take place peaccably; but if the molecula are brought into contact abruptly, the caloric is difengaged with the greateft violence. It is to this rapid difengagement of caloric, ftrongly compreffed, that we ought to afcribe the detonations of the fuper-oxygenated muriat of pot-afh and of gun-powder.

The moleculæ affumed, for example, retain a portion of the compreffed caloric as long as they obey the force which makes them approach each other. When they arrive at that diftance at which they excrife an action on each other, their attractive force is greater or lefs than that with which their atmofpheres tend to recover their former ftate. If the molecula, then, be left to themfelves, in the firit cafe the fyftem retains its prefent ftate; in the other cafe it will refume its primitive ftate; and it is in this that the greater part of the phenomena of elafticity feen to confift. This reafoning may be applied to every body, the molecula of which are feparated from each other by a certain quantity of caloric.

C. Barruel pays attention alfo to the circumftances under which the elafticity of a body may be manifefted, and to the means proper for increafing or producing this property. Thefe circumftances are, comprefion, a fudden fhock, and flexion. In either of thefe circumftances it happens that the adherence of the moleculæ either is or is not overcome. In the firt cafe the moleculæ are put out of their fphere of activity, and the body is faid to be brittle. In the fecond cafe the body is flexible, but the caloric interpofed between its moleculæ withdraws, or does not withdraw itfelf, from comprefion. If it withdraws itfelf, there is only one dif- 
placement of the particles of the body, which is then fard to be ducile. If it cannot withdraw itfelf, it yiehds or refifts. When it yields, the body is foft; when it refffts comprelfion, it experiences the effects of it as long as the molecula are compreffed; it then tends to recover its former ftate; and this is what renders bodies elaftic.

There is no body perfectly foft, duetile, or elaftic. Nature prefents nome which under compreffion does not fuffer a portion of caloric to efcape. Thus a body is never perfectly elaftic, becaufe the quantity of caloric compreffed, being lefs than the total quantity, cannot reftore itfelf with the fame force as if this fluid had remained in its entire ftate, and cannot keep the molecula of the body feparated at the fame diftance as before compretion. Befides, the velocity with which it reftores itfelf is alfo lefs than that which produced the compreffion, for a part of this velocity has been deftroyed by the entire mals of the compreffed body.

A body is more flexible according as it contains more caloric between its moleculæ. This very comprefible fluid permits concave molecule to approach each other withont the convex molecula being obliged to fiparate from each other, as if there were not caloric interpoted between them.

The preceding obfervations may ferve to throw fome hight on various phenomena of elalticity. A blade of copper not hammered evidently remains in that ftate into which it is put by bending, becaufe the molecula of the concave part exprefs, by approaching each other, that portion of caloric which adheres leat to them. The other portion, which does not cluape, is indeed compreffed; but the excefs of the fpring is compenfated by the excefs of the adherence of the molecule brought together: the body remains in that ftate in which it is placed.

If the blade has been hammered, it lofes by that operation a portion of caloric; the other portion remains compreffed; and, when this blade is bent, the compreffion of the fluid is increafed. The excefs of fpring which it acquires is not counterbalanced by the excefs of the adherence of the mo lecula: it tends to reftore itfell; and the body pafes to that fate which is called oly.tim 
The compreffion and re-eftablidiment of caloric may ferve to explain alfo the ofcillations of the molecula of a tabe of glafa terminated by a ball of the fame nature, when rubbed with a moiltened fponge in order to obtain from it acute tones. The moleculæ of the tube having, by the extenfion which it experiences, quitted the pofition proper for their equilibrium, tend to return to it; and as by the velocity acquired they go beyond the term from which they fet out, the interpofed caloric is compreffed, it re-eftablifhes itfelf with a force equal to the comprefion, and repels the two parts of the tube to the diftance at which they were at firt, which occalions an ofcillatory motion until it has been deftroyed by the refiftance of the air.

We might, ftrictly fpeaking, explain; without the intervention of caloric, the clafticity of the ftring of a violin, or of a bell, put into vibration: but from what has been faid, it feems to act the moft confpicuous part.

Elafticity manifefts itfelf with lefs energy in liquids than in folids, and yet the former contain more caloric. The reafon is plain; it is becaufe their noleculæ, being exceedingly moveable, they can eafly withdraw themfelves from the compreffing forces; but they are elaftic, fince they have the property of tranimitting founds, and of recoiling back on themfelves.

It mint have been remarked, that the accumulation of caloric diminithes the fpring of folid or fluid bodies: in gafeous bodies, on the other hand, this clafticity is increafed by the accumulation, becaufe thefe bodies, being held in folution in the caloric, participate in its mechanical properties, and chiefy its elafticity.

To increafe or produce elafticity in certain bodies, we mute employ means proper for bruging together their molecula, and kecping the caloric in a fuce of great compreffion. The harder, therefore, that a body is, provided it is not fo in the extreme degree, the more it will be claftic. It becomes, indeed, lefs fiexible; but this ineonvenience may be remedied by rendering the budy i.in, fince its moleculia will then be lefs difplaced duriag flexion. There are two things, then, to be confidered in claficity; the rapidity of 
the difplacement of the parts put in motion, and the exterit of the difplacement, which depend on flexibility.

Allaying and tempering favour the increafe of elafticity; becaufe, thefe operations, by bringing the moleculæ nearer to each other, comprefs the caloric, which tends afterwards to re-eftablith itfelf. All thefe facts have induced the author to conclude, that caloric has at lcait a great thare in all the phenomena exhibited by elafticity.

\section{On the Efficacy of $Y_{e} /$ in the Cure of thofe Difeafes known by the Name of Putrid*.}

A Remedy, which contains much fixed air, has been lately ftarted by the Rev. Mr. Cartwright, which merits the higheft attention. Seventeen years ago, fays this gentleman, I wont to refide at Brampton, a very populous village near Chefterfield. $I$ had not been there many months before a putrid fever broke out among us : finding by far the greater number of my: new parifhioners much too poor to afford themfelves medical affiftance, I undertook, by the help of fuch books on the rubject of medicine as were in my poffeffion, to prefcribe for them. I early attended a boy about fourteen years of age, who was attacked by this fever; he had not been ill many days-before the fymptoms were unequivocally putrid. I then adminiftered bark, wine, and fuch other remerlies as my book directed. My exertions, however, were of no a vail; his diforder grew every day more untractable and mal!gnane, fis that 1 was in hourly expectation of his diffution. Bung maler the abfolute neceflity of taking a joursey, bcfore I ct of I went to fee him, as I thouglit, for the laft time, and I prepared his parents for the event of his dath, which I confidered as inevitable, and reconriled them in the beft manner I was able to a lofs which I knew they would feel ferercly. While I was in converfation on this diftreing fubjed with his mo-

* The contents of this article cannot be too generally kuown. How many valuable lives are gearily loft by phitrid fore theats, ferers, $d e$. which migint be fived to the onsmunty, and to their velinives, if the cure here iccommended were gaidrally lanown and rethes to! with proper

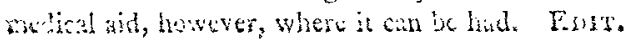

